\title{
Epigallocatechin gallate and genistein attenuate glial fibrillary acidic protein elevation induced by fibrogenic cytokines in hepatic stellate cells
}

\author{
CHUNYAN ZHANG and LANG ZHUO
}

Institute of Bioengineering and Nanotechnology, 31 Biopolis Way, the Nanos, \#04-01, 138669 Singapore

Received June 13, 2006; Accepted August 24, 2006

\begin{abstract}
Hepatic stellate cells (HSCs) play a pivotal role in hepatic fibrogenesis, and are considered a cellular target for therapeutic intervention. We recently established that a $2.2-\mathrm{kb}$ hGFAP (human glial fibrillary acidic protein) promoter could be used to specifically target cultured HSCs. In the current study, we aimed to investigate whether the same transgene (2.2-kb hGFAP-lacZ) can be used as a biomarker for studying the inhibition of HSC activation. HSC-T6 cells stably transfected with the transgene were treated with two natural anti-fibrotic compounds, epigallocatechin gallate (EGCG) and genistein separately. Results showed that both transgenic ß-galactosidase activity and endogenous GFAP expression (mRNA and protein) were attenuated by EGCG or genistein treatment in a dose- and time-dependent manner. Our data further demonstrated that the suppression of fibrogenic endpoints was primarily mediated through the inhibition of AP-1 signaling (and to a lesser degree through the NFKB pathway) onto the GFAP promoter. In conclusion, the current findings provide a proof-of-concept for using GFAP for studying HSC activation and inhibition. It could be envisioned that a HSCbased high-throughput system can be constructed using the GFAP promoter in conjunction with a real-time reporter for the screening of anti-fibrotic and anti-inflammatory agents.
\end{abstract}

\section{Introduction}

Hepatic stellate cells (HSCs) play a critical role in hepatic fibrogenesis during chronic liver injuries inflicted by diverse

Correspondence to: Dr Lang Zhuo, Institute of Bioengineering and Nanotechnology, 31 Biopolis Way, the Nanos, \#04-01, 138669 Singapore

E-mail: lzhuo@ibn.a-star.edu.sg

Abbreviations: HSC, hepatic stellate cell; GFAP, glial fibrillary acidic protein; SMAA, smooth muscle $\alpha$-actin; EGCG, epigallocatechin gallate; TGF- $\beta 1$, transforming growth factor- $\beta 1$; PDGF-BB, plateletderived growth factor; AP-1, activation protein-1; NFKB, nuclear factor кB; NF-1, nuclear factor-1; EMSA, electrophoretic mobility shift assay

Key words: hepatic stellate cells, glial fibrillary acidic protein, hepatic fibrosis, hepatic inflammation, epigallocatechin gallate, genistein, activation protein, $\mathrm{NF} \kappa \mathrm{B}$ insults. Much of the molecular mechanisms leading to hepatic fibrosis have been elucidated in the past two decades. Particularly the elevation of key pro-fibrotic cytokines, such as transforming growth factor (TGF-B1) and platelet-derived growth factor (PDGF-BB), has been recognized as a major factor for mediating hepatic fibrosis (1).

We recently demonstrated that the GFAP promoter was not only capable of directing HSC-specific expression, but also responding to TGF- 31 by up-regulating transgene expression (2) in the rat HSC-T6 cell line (3). To investigate whether the same transgene is further capable of reporting suppression of HSC activation, the same cell clone (T6/GFAP-lacZ) was treated with two natural compounds (EGCG and genistein), which were known to have inhibitory effects on HSC activation and proliferation $(4,5)$. Results showed that transgene expression, as well as endogenous GFAP gene expression, were significantly suppressed by EGCG or genistein treatment in a dose- and time-dependent manner. Furthermore HSC activation induced by TGF- 31 or PDGF-BB (as judged by the up-regulation of both transgenic and endogenous GFAP expression) was substantially attenuated by EGCG or genistein. In reference, the traditional biomarker for HSC activation was also suppressed by EGCG or genistein in the T6/GFAP-lac $Z$ cells. Thus the current findings extended the utilities of the transgenic GFAP-lacZ surrogate from being a highly specific maker for HSCs (2) to a quantitative biomarker for studying the HSC activation and inhibition during fibrogenesis and reversion.

\section{Materials and methods}

Cell culture. The rat HSC-T6 cell line (3) was previously transfected with a GFAP-lacZ reporter transgene and resulted in a stable clone termed T6/GFAP-lacZ (2), which was used in all experiments in the current study. The cell method, medium and reagents used were essentially as previously described (2).

Cell treatment with TGF- $\beta 1, P D G F-B B, E G C G$ and genistein. EGCG (cat. no. E4143) and genistein (cat. no. G6649) were purchased from Sigma Chemicals (St. Louis, MO, USA) and used without further purification. Stock solutions were prepared in DMSO. The final DMSO concentration in the culture medium was kept below $0.2 \%$. Recombinant human TGF- 31 and PDGF-BB were purchased from BioVision (CA, 
Table I. DNA oligonucleotide sequences for EMSA.

\begin{tabular}{lllc}
\hline Sites & \multicolumn{1}{c}{ Oligo names } & \multicolumn{1}{c}{ Sequences } & References \\
\hline AP-1 & SC oligo & 5' CGCTTGATGACTCAGCCGGAA 3' & Santa Cruz Biotechnology \\
& hGFAP promoter oligo 1 & -1603 TGCCCAGTGAATGACTCACCT-1577 & $(13)$ \\
& hGFAP promoter oligo 2 & -1599 CAGTGAATGACTCACCTTGGC-1573 & $(13)$ \\
& hGFAP promoter oligo 3 & -1593 ATGACTCACCTTGGCACAGACACAATGTT-1565 & $(13)$ \\
& rGFAP promoter oligo & -1526 CACTGAATGACTCACCTTGGC-1506 & Santa Cruz Biotechnology \\
NFkB & SC oligo & 5' AGTTGAGGGGACTTTCCCAGGC 3' & $(13)$ \\
& hGFAP promoter oligo & -84 ATGCCAGGGGGTGTTGCCAGGG-63 & $(12)$ \\
& rGFAP promoter oligo & -85 ATTCAATGGGGTGCTGCCAGGAA-63 &
\end{tabular}

AP-1 and NFאB consensuses are underlined, and the NF-1 site is in bold italics.

USA). Cells were initially seeded in 12-well plates in DMEM supplemented with $10 \%$ FBS and weaned to low serum (0.5\% FBS) DMEM at a confluence of $70-80 \%$ for an additional $12 \mathrm{~h}$ of adaptation. Cells were then incubated with different concentrations of compounds for various time points before being assayed for $B$-galactosidase activity, GFAP mRNA and various protein expression. For compound attenuation studies, cells were treated with a pro-fibrotic cytokine (TGF-B1 or PDGF-BB) either sequentially or concurrently with a compound (EGCG or genistein). In the sequential scheme, cells were first treated with a cytokine for 1-3 days, then the cytokine-containing culture medium was replaced with a fresh medium containing a particular compound for various time points. Details of the cytokine/ compound treatments are described in the individual figure legends.

$X$-gal staining and quantification of $\beta$-galactosidase activity. In situ expression of GFAP-lacZ transgene was detected by an assay kit from InvivoGen (CA, USA). Staining results were documented with a digital camera (DP12) attached to an Olympus inverted bright field microscope (IX51) after development for $60 \mathrm{~min}$. For quantitative study, B-galactosidase activity in the cell extracts was measured using a chemiluminescent assay kit (Roche, Mannheim, Germany) in a 96well plate format, according to the manufacturer's instructions. Briefly, cells were washed twice with ice-cold 1X PBS ( $\mathrm{pH} 7.4$ ), lysed for $30 \mathrm{~min}$ at room temperature in the lysis buffer, and the supernatant was collected for assay. The protein concentration was determined with a BCA protein assay kit (Pierce, IL, USA). Specific $\beta$-galactosidase activity was obtained by normalizing against the total cellular protein content.

Real-time RT-PCR for endogenous rat GFAP $m R N A$. Total RNA was extracted using a NucleoSpin RNA II kit (MachereyNagel, Germany) and quantified by an ND-100 spectrophotometer (Nanodrop Technologies, DE, USA). Total RNA was firstly reverse transcribed to cDNA using Taqman's reverse transcription reagent (Applied Biosystems, CA). A total of $200 \mathrm{ng}$ RNA in $7.7 \mu \mathrm{l}$ of nuclease-free water was added to $2 \mu 110 \mathrm{X}$ reverse transcriptase buffer, $4.4 \mu 125 \mathrm{mM}$ magnesium chloride, $4 \mu 1$ deoxyNTP mixtures, $1 \mu 1$ random

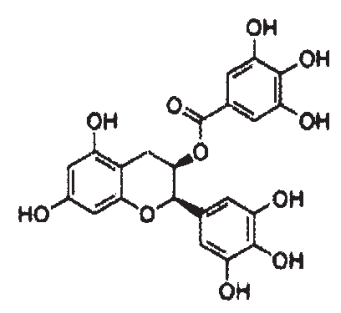

Epigallocatechin-3-gallate (EGCG)

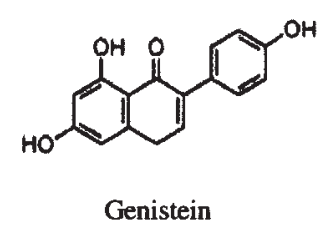

Figure 1. Chemical structures of EGCG and genistein.

hexamers, $0.4 \mu 1 \mathrm{RNa}$ se inhibitor and $0.5 \mu 1$ reverse transcriptase $(50 \mathrm{U} / \mu 1)$ in a final reaction volume of $20 \mu 1$. The reaction was performed for $10 \mathrm{~min}$ at $25^{\circ} \mathrm{C}$ (annealing), $30 \mathrm{~min}$ at $48^{\circ} \mathrm{C}$ (cDNA synthesis) and $5 \mathrm{~min}$ at $95^{\circ} \mathrm{C}$ (enzyme denaturation).

Real-time quantitative PCR was carried out with an ABI 7500 fast real-time PCR system (Applied Biosystems, CA). Sample cDNA $(2 \mu 1)$ was used in each PCR reaction, with $\beta$ actin gene as a reference for normalization. Primers and probes for rat $\beta$-actin and GFAP were ordered from Taqman's assay-on-demand database. The PCR reaction was performed under default profile consisting of $95^{\circ} \mathrm{C}$ for $20 \mathrm{sec}$ (enzyme denaturation) and 40 cycles of amplification (denaturation of $3 \mathrm{sec}$, annealing and extension of $30 \mathrm{sec}$ ). Some of the real-time RT-PCR products were separated on agarose gel for visual confirmation of discrete products (data not shown).

Relative quantitation of target mRNA was calculated using the comparative threshold cycle $\left(\mathrm{C}_{\mathrm{T}}\right)$ method as described in User bulletin \#2 (ABI PRISM 7700 sequence detection system). $C_{T}$ indicates the fractional cycle number at which the amount of amplified target reaches a fixed threshold within 


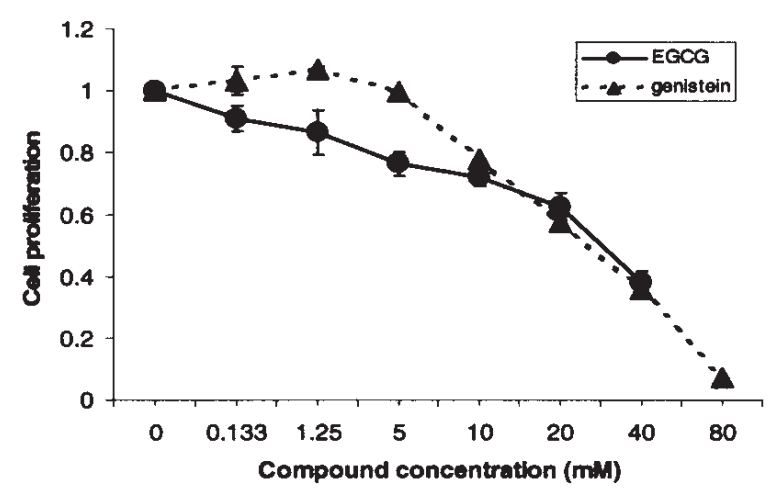

Figure 2. Suppression of T6/GFAP-lacZ cell proliferation by EGCG and genistein as indicated by MTS assay. Cells were grown in full medium to 70$80 \%$ confluence in 96 -well plates, followed by compound treatment of various concentrations $(0-80 \mu \mathrm{M})$ in low serum DMEM for $48 \mathrm{~h}$ before assaying for proliferation. Signal was normalized against vehicle treatment (0 $\mu \mathrm{M}$ compound). Data was obtained from three independent experiments and presented as mean \pm SEM. IC50 was $31 \mu \mathrm{M}$ for EGCG and $25 \mu \mathrm{M}$ for genistein respectively.

the linear phase of gene amplification. $\Delta \mathrm{C}_{\mathrm{T}}$, which reflects the difference between $\mathrm{C}_{\mathrm{T}}$ target and $\mathrm{C}_{\mathrm{T}} \beta$-actin, is inversely correlated to the abundance of mRNA transcripts in the samples. $\Delta \mathrm{C}_{\mathrm{T}}$ for each sample was normalized against the control experiment or calibrator and expressed as $\Delta \Delta \mathrm{C}_{\mathrm{T}}$. Relative quantitation is given by $2^{-\Delta \Delta C T}$ to express the upregulation or down-regulation of the target gene under the treatments compared to the control.

Western blotting. For GFAP blotting, protein extracts were prepared by lysing the cell pellet in 10 volumes of boiled $1 \% \operatorname{SDS}\left(90-95^{\circ} \mathrm{C}\right)$ for $10 \mathrm{~min}$ and quantified by a BCA kit (Pierce). Nuclear and cytoplasmic proteins were extracted using NE-PER nuclear and cytoplasmic extraction reagents from Pierce and quantified by the BCA method. Nuclear proteins were used for blotting transcription factor protein while cytoplasmic protein was used for blotting SMAA. Generally, $15 \mu \mathrm{g}$ of the protein samples were mixed with NuPAGE LDS sample buffer and NuPAGE reducing agent (Invitrogen, CA) and heated at $70^{\circ} \mathrm{C}$ for $10 \mathrm{~min}$. Samples were then separated in 4-12\% gradient NuPAGE Novex Bis-Tris gel in NuPAGE MOPS SDS running buffer (Invitrogen) under $200 \mathrm{~V}$ for $50 \mathrm{~min}$. After transfer on to a Hybond nitrocellulose membrane (Amersham Biosciences, NJ, USA), the blots were blocked in $5 \%(\mathrm{w} / \mathrm{v})$ skimmed milk overnight, incubated with 1:1000 diluted primary antibodies against GFAP (Dako, Denmark), SMAA (Sigma), c-Jun, c-fos, Jun B, Jun D, Fra-1, Fra-2 (Santa Cruz Biotechnology, CA) or $\mathrm{NF \kappa B}$ (Abcam, UK) respectively at room temperature for $1 \mathrm{~h}$, washed four times in PBS containing 0.1\% Tween-20 (PBS-T), and incubated with 1:1000 diluted horseradish peroxidaseconjugated secondary antibody (Santa Cruz Biotechnology) at room temperature for $1 \mathrm{~h}$ and washed four times with PBS-T. Protein bands were then recorded on X-ray film by reacting with ECL Plus chemiluminescence reagents (Amersham Biosciences) and quantified by densitometry using AlphaDigi Doc RT software (Alpha Innotech, CA).

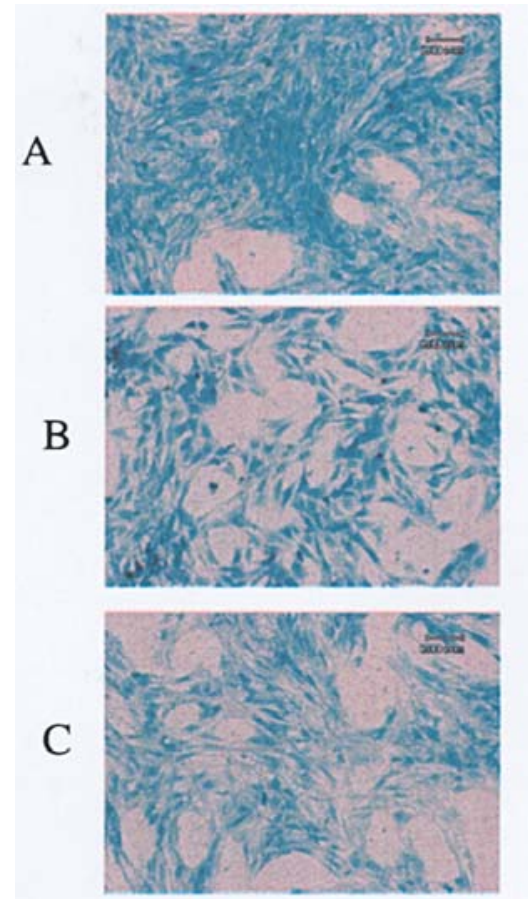

Figure 3. Suppression of B-galactosidase expression and cell proliferation by EGCG and genistein as indicated by X-gal staining of T6/GFAP-lacZ cells. Cells were grown in full medium to $70-80 \%$ confluence in 6-well plates, followed by incubation with (A) vehicle control, (B) $25 \mu \mathrm{M}$ EGCG, and (C) $40 \mu \mathrm{M}$ genistein in low serum DMEM for $24 \mathrm{~h}$. Images were captured after $60 \mathrm{~min}$ of X-gal staining. Scale bar $=60 \mu \mathrm{m}$.

Electrophoretic mobility shift assay (EMSA). Oligonucleotide sequences used for EMSA are listed in Table I. Singlestranded oligos were end biotinylated by using a Biotin 3 end labeling kit (Pierce). Reaction mix was prepared by mixing $100 \mathrm{nM}$ oligo in $35 \mu 1$ ultrapure water, $5 \mu 1$ of $5 \mathrm{X}$ TdT reaction buffer, $5 \mu 1$ of $5 \mu \mathrm{M}$ biotin-11-UTP and $5 \mu 1$ of $2 \mathrm{U} / \mu 1$ $\mathrm{TdT}$ in a final $50 \mu 1$ volume and incubated at $37^{\circ} \mathrm{C}$ for $30 \mathrm{~min}$. After the reaction was stopped by $2.5 \mu 10.2 \mathrm{M}$ EDTA, $50 \mu \mathrm{l}$ chloroform:isoamyl alcohol was added to the reaction mix to extract the TdT. The aqueous phase containing biotin-labeled oligo was collected after centrifugation at high speed for $2 \mathrm{~min}$. For EMSA application, biotin-labeled single-stranded oligos were annealed to double-stranded oligos by mixing an equal amount of labeled complementary oligos and incubating for $1 \mathrm{~h}$ at room temperature.

EMSA assay was performed using Pierce's LightShift chemiluminescent EMSA kit (Pierce) according to the manufacturer's instructions. A complete reaction included addition of a) $20 \mathrm{fmol}$ biotin-labeled oligo alone, which determined the position of an unshifted probe band; b) $20 \mathrm{fmol}$ biotin-labeled oligo and $10 \mu \mathrm{g}$ nuclear protein extract, which detected the shifted probe band by protein-oligo binding and c) biotin-labeled oligo, 5-10 $\mu \mathrm{g}$ nuclear protein extract and 200-fold molar excess of unlabeled oligo, which demonstrated that the shift observed in $b$ was prevented by competition from excess non-labeled oligo. Binding reaction was carried out in a reaction buffer containing $10 \%$ glycerol and $50 \mathrm{ng} / \mu 1$ poly $(\mathrm{dI} \triangleleft \mathrm{dC})$ at room temperature for $20 \mathrm{~min}$. The reaction mix was then resolved in pre-cast $6 \%$ DNA retardation gel (Invitrogen) by electrophoresis in TBE under $100 \mathrm{~V}$, 
transferred and immobilized on a nylon membrane by UV cross-linking. Finally, protein-oligonucleotide binding was detected through the biotin tag, which was recognized by 1:300 diluted streptavidin-horseradish peroxidase conjugate and recorded on X-ray film by chemiluminescence.

Statistical analysis. All quantitative results were presented as mean \pm SEM. Experimental data were analyzed using two-tailed Student's t-test assuming unequal variances. A $\mathrm{P}$-value $=0.05$ was considered statistically significant.

\section{Results}

EGCG and genistein inhibited HSC-T6 cell proliferation. EGCG is a major catechin from green tea leaves associated with a wide range of beneficial activities including antioxidation, anti-inflammation and anti-fibrosis, whereas genistein is a major flavonoid found abundantly in soy bean with anti-tumor and pro-apoptotic activities. Their chemical structures are illustrated in Fig. 1. Several reports have shown that these two compounds inhibited cell proliferation of HSCs at different activation or transformation statuses (4-7). To ensure that the observed responsive characteristics were preserved in the transformed T6/GFAP-lacZ cells (2), cells were treated with $25 \mu \mathrm{M}$ of EGCG or $40 \mu \mathrm{M}$ of genistein for $24 \mathrm{~h}$ in low serum (0.5\% FBS) DMEM. Then the cells were fixed and stained with X-gal substrate for $60 \mathrm{~min}$ prior to photography. It was apparent that cells treated with EGCG (Fig. 3B) and genistein (Fig. 3C) displayed significant proliferation inhibition, as evident by fewer cells as compared to the control (Fig. 3A). IC50 values of EGCG and genistein for inhibiting the cell proliferation were determined to be $31 \mu \mathrm{M}$ and $25 \mu \mathrm{M}$ respectively in low serum $(0.5 \%$ FBS) medium (Fig. 2), by using a tetrazolium-based MTS proliferation assay kit (Promega, WI, USA). The EGCG IC50 value obtained for the T6/GFAP-lacZ cells was in a comparable range to those reported for the activated (8) and immortalized human HSCs (9), and for the primary rat HSCs $(4,6)$. However our genistein IC50 value for the T6/GFAP-lacZ cells was three times lower than that for T6 cells cultured in DMEM containing 10\% FBS (7). Our additional data also confirmed that no significant difference in IC50 value was observed between the T6 and the T6/GFAP-lac $Z$ cells (data not shown).

EGCG suppressed GFAP expression. No background endogenous $\beta$-galactosidase activity was detected by using a chemiluminescent assay kit in untransfected T6 cell extracts (data not shown). In contrast, significant $\beta$-galactosidase activity was reliably detected in the T6/GFAP-lacZ cells (Fig. 4A). Interestingly, a rapid and significant suppression of the transgene expression (representing 82 or $55 \%$ of the control respectively) was observed in cells treated with $5 \mu \mathrm{M}$ or $20 \mu \mathrm{M}$ of EGCG for merely $2 \mathrm{~h}$. The initial suppression seemed to be transient by nature, since the only suppression (at $73 \%$ of the control level) observed at the 4-h time point was caused by the treatment with $20 \mu \mathrm{M}$ of EGCG, the highest concentration used in this particular experiment. When the treatment was prolonged to $24 \mathrm{~h}$, the EGCG inhibitory effect was completely abolished for all dosages. The mechanism for
A

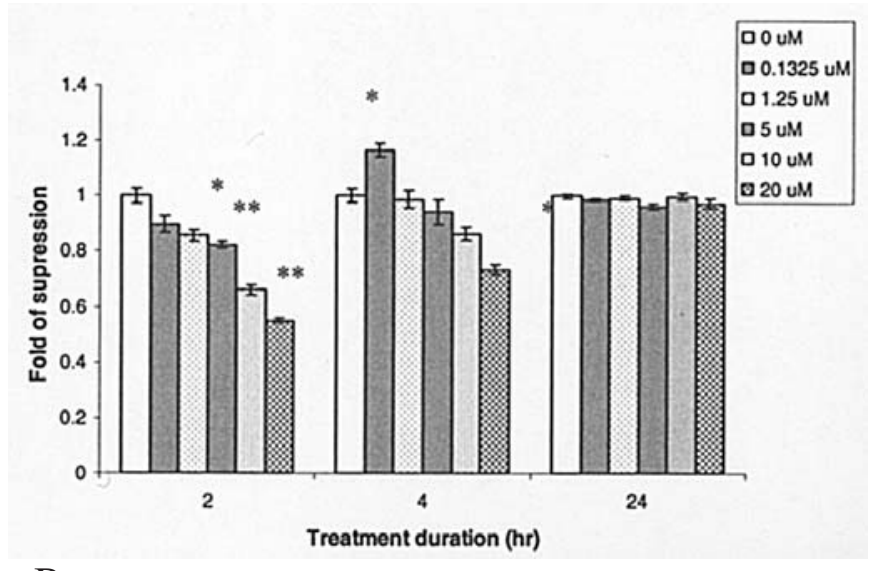

B

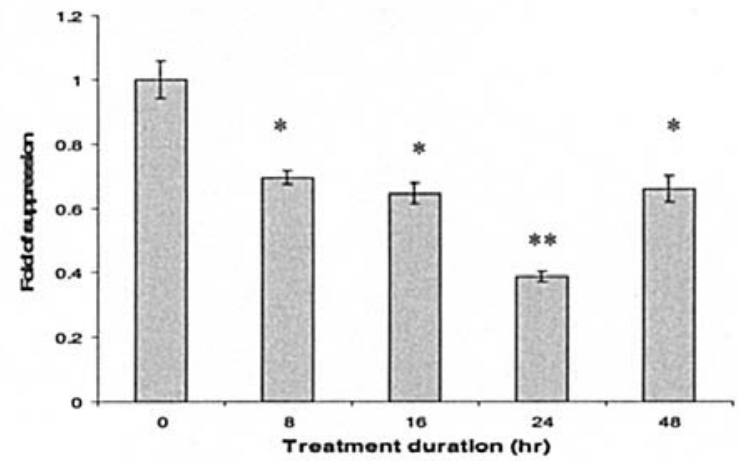

C

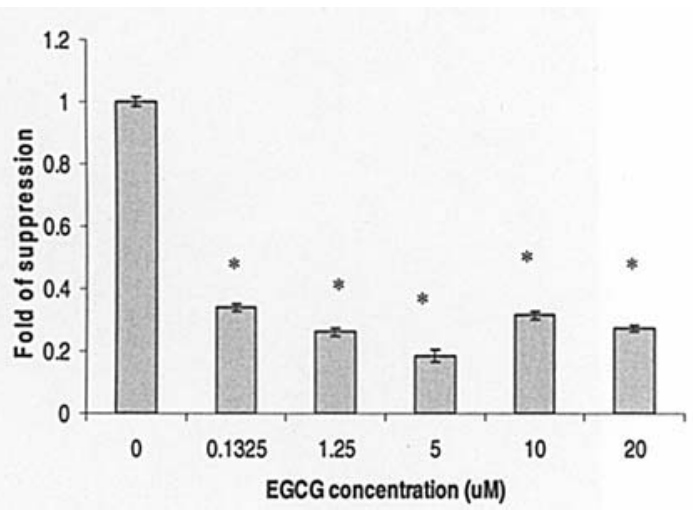

Figure 4. (A) Time- and dose-dependent suppression of GFAP-lacZ by EGCG. B-galactosidase activity was assayed for treatment with different concentrations of EGCG $(0,0.1325,1.25,5,10$ and $20 \mu \mathrm{M})$ at different time points $(2,4$, and $24 \mathrm{~h})$. Data are presented as mean \pm SEM. $\mathrm{n}=6,{ }^{*} \mathrm{P}<0.05$, ${ }^{* *} \mathrm{P}<0.001$, when compared to control $(0 \mu \mathrm{M})$. (B) Time-dependent suppression of GFAP mRNA by EGCG. T6/GFAP-lacZ cells were incubated with $10 \mu \mathrm{M}$ of EGCG in low serum DMEM for various time points $(0,8,16,24$ and $48 \mathrm{~h})$, and endogenous rat GFAP mRNA was quantified with real-time RT-PCR. Data were presented as mean \pm SEM. $n=6,{ }^{*} \mathrm{P}<0.05$, ${ }^{* *} \mathrm{P}<0.01$, when compared to treatment at $0 \mathrm{~h}$. (C) Dose-dependent suppression of GFAP mRNA by EGCG. T6/GFAP-lac Z cells were treated with various doses of EGCG $(0,0.1325,1.25,5,10$, and $20 \mu \mathrm{M})$ in low serum DMEM for $48 \mathrm{~h}$, and endogenous rat GFAP mRNA was quantified with real-time RT-PCR. Data were presented as mean \pm SEM. $n=6,{ }^{*} \mathrm{P}<0.001$, when compared to treatment with $0 \mu \mathrm{M}$.

the observed phenomenon was not clear, but was probably due to the rapid depletion of active EGCG metabolite(s) by cellular metabolism and/or cellular adaptation. It has been 
A

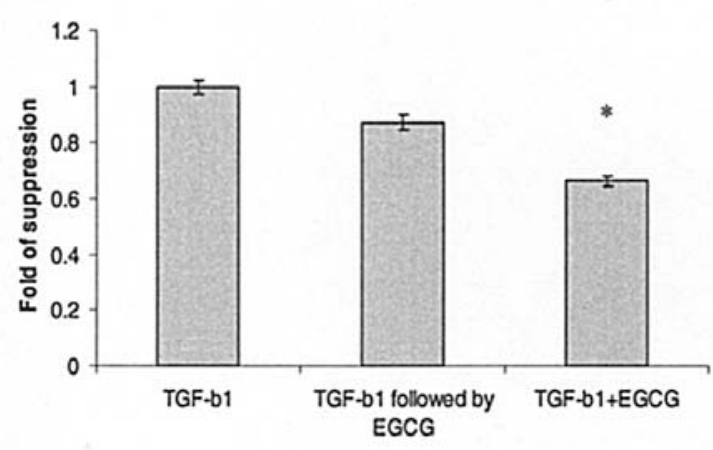

B

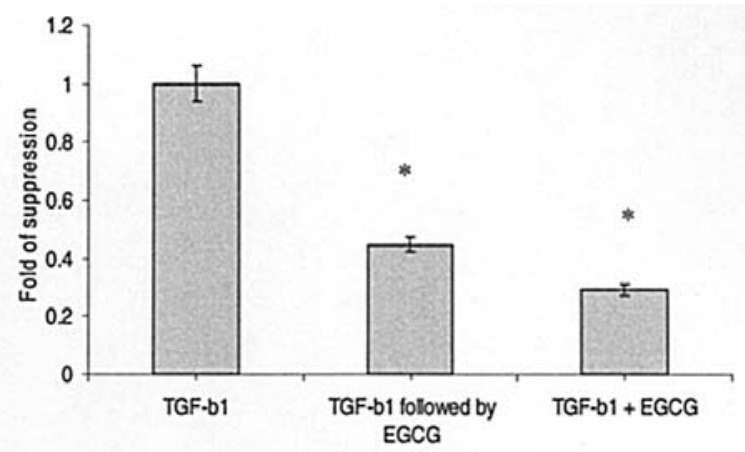

Figure 5. (A) Attenuation of TGF-ß1-induced GFAP-lacZ elevation by EGCG. T6/GFAP-lacZ cells were treated with $10 \mathrm{ng} / \mathrm{ml}$ TGF-ß1 for $24 \mathrm{~h}$ (left column); with $10 \mathrm{ng} / \mathrm{ml}$ TGF- 31 for $24 \mathrm{~h}$ followed by $20 \mu \mathrm{M}$ of EGCG for an additional $2 \mathrm{~h}$ (middle column); and with $20 \mu \mathrm{M}$ of EGCG and $10 \mathrm{ng} / \mathrm{ml} \mathrm{TGF}-\beta 1$ for $26 \mathrm{~h}$ (right column). Data are presented as mean \pm SEM. $n=6,{ }^{*} \mathrm{P}<0.005$, when compared to $10 \mathrm{ng} / \mathrm{ml}$ TGF- $\beta 1$-treated-alone control (left column). (B) Attenuation of TGF-ß1-induced GFAP mRNA elevation by EGCG. T6/GFAP-lacZ cells were treated with $1 \mathrm{ng} / \mathrm{ml}$ TGF- $\beta 1 \mathrm{for} 48 \mathrm{~h}$ (left column); with $1 \mathrm{ng} / \mathrm{ml}$ TGF- 31 for $48 \mathrm{~h}$ followed by $5 \mu \mathrm{M}$ of EGCG for an additional $8 \mathrm{~h}$ (middle column); and with $5 \mu \mathrm{M}$ of EGCG and $1 \mathrm{ng} / \mathrm{ml} \mathrm{TGF}-\beta 1 \mathrm{for} 56 \mathrm{~h}$ (right column). Data are presented as mean \pm SEM. $\mathrm{n}=6,{ }^{*} \mathrm{P}<0.001$, when compared to $1 \mathrm{ng} / \mathrm{ml}$ TGF-ß1-treated-alone control (left column).

A

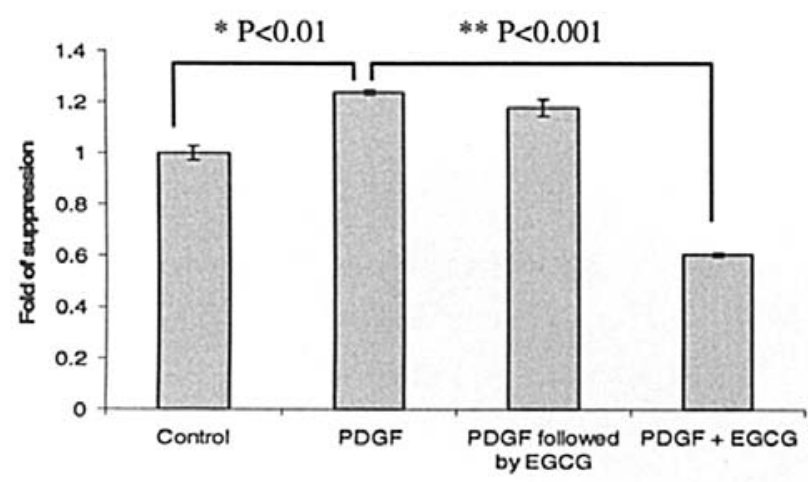

$\mathrm{B}$

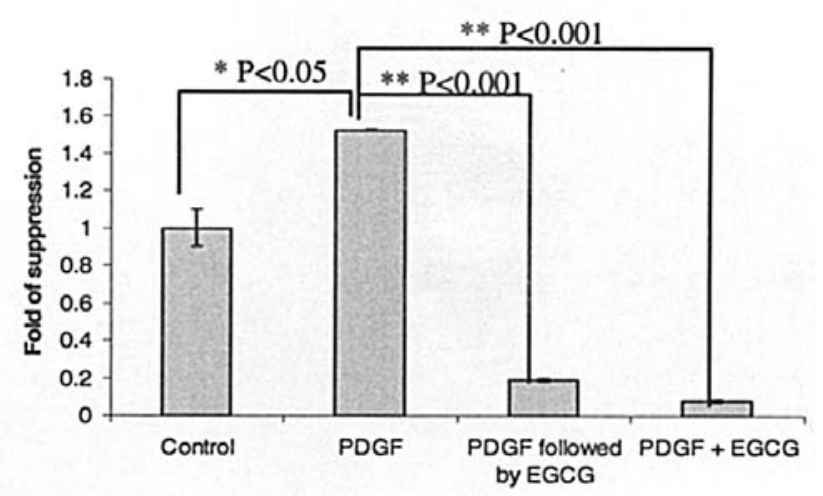

Figure 6. (A) Attenuation of PDGF-induced GFAP-lacZ activation by EGCG. T6/GFAP-lacZ cells were subjected to different treatments and ß-galactosidase activity was assayed. From left to right: column 1, vehicle control; column 2, $10 \mathrm{ng} / \mathrm{ml}$ PDGF-BB for $48 \mathrm{~h}$; column $3,10 \mathrm{ng} / \mathrm{ml}$ PDGF for $48 \mathrm{~h}$ followed by $20 \mu \mathrm{M}$ of EGCG for an additional $2 \mathrm{~h}$; and column 4, $20 \mu \mathrm{M}$ of EGCG and $10 \mathrm{ng} / \mathrm{ml} \mathrm{PDGF}$ for $50 \mathrm{~h}$. Data are presented as mean $\pm \mathrm{SEM}$. $\mathrm{n}=6$, ${ }^{*} \mathrm{P}<0.01$, ${ }^{* *} \mathrm{P}<0.001$. (B) Attenuation of PDGF-induced GFAP mRNA expression. T6/GFAP-lacZ cells were subjected to different treatments and mRNA was quantified by realtime RT-PCR. From left to right: column 1, vehicle control; column 2, $10 \mathrm{ng} / \mathrm{ml}$ PDGF for $24 \mathrm{~h}$; column $3,10 \mathrm{ng} / \mathrm{ml}$ PDGF for $24 \mathrm{~h}$ followed by $10 \mu \mathrm{M}$ of EGCG for an additional $24 \mathrm{~h}$; and column $4,10 \mu \mathrm{M}$ of EGCG and $10 \mathrm{ng} / \mathrm{ml}$ PDGF for $48 \mathrm{~h}$. Data are presented as mean $\pm \mathrm{SEM}$. $\mathrm{n}=6$, ${ }^{*} \mathrm{P}<0.05,{ }^{* *} \mathrm{P}<0.001$.

reported that EGCG half-life in human plasma is about $5 \mathrm{~h}$ (10). Another interesting feature was that the maximum suppression of GFAP-lacZ transgene (55\% of the control) by EGCG was observed after $2 \mathrm{~h}$ of incubation (Fig. 4A), whereas the maximum suppression on the endogenous GFAP ( $39 \%$ of the control) was seen at $24 \mathrm{~h}$ after compound addition (Fig. 4B). Similarly, the expression of the transgene returned to the non-treated level earlier than that of the endogenous GFAP. Previously, an earlier response by the same transgene was also noted for the TGF- $B 1$ induction (2). The EGCG dosage effect on endogenous GFAP transcription was also investigated. At $133 \mathrm{nM}$, a concentration significantly below the IC50 value (31 $\mu \mathrm{M})$, GFAP transcription was significantly suppressed to $34 \%$ of the control level, suggesting that EGCG is a potent inhibitor of GFAP transcription in HSCs (Fig. 4C). The minimum concentration of EGCG capable of causing significant inhibition of GFAP transcription was not systematically investigated in the current study. On the other hand, no further suppression was observed with increasing concentrations up to $20 \mu \mathrm{M}$.

EGCG attenuated GFAP elevation induced by TGF- $\beta 1$ or $P D G F-B B$. We recently reported that the expression of endogenous and transgenic GFAP was induced by TGF- $B 1$ in a dose- and time-dependent manner in the T6/GFAP-lacZ HSC line (2). To investigate whether cytokine-induced elevation in GFAP-lacZ and GFAP can be attenuated by EGCG, cells were subject to 1 or $10 \mathrm{ng} / \mathrm{ml}$ of TGF- $\beta 1$ treatment either sequentially or concurrently with different concentrations of EGCG for various time points prior to assaying for B-galactosidase activity and GFAP mRNA. For comparison purpose, assay values from cells treated with TGF-B1 or PDGF-BB alone were normalized to 1 for all attenuation experiments. As shown in Fig. 5A, B-galactosidase activity in cells treated with 
A

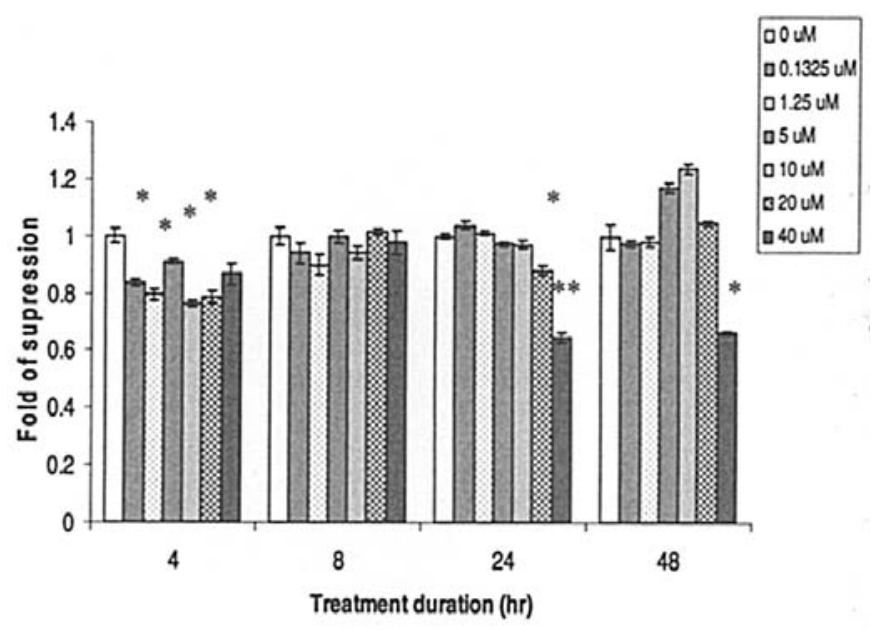

B

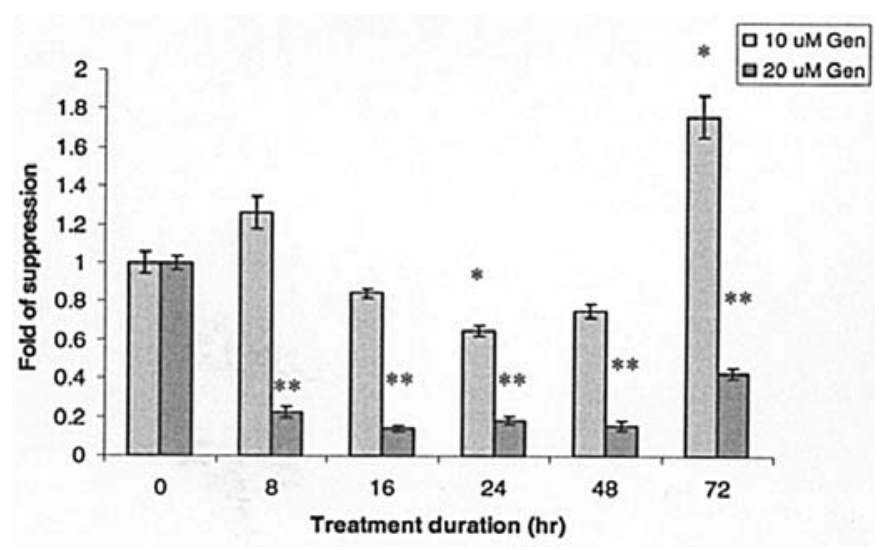

$\mathrm{C}$

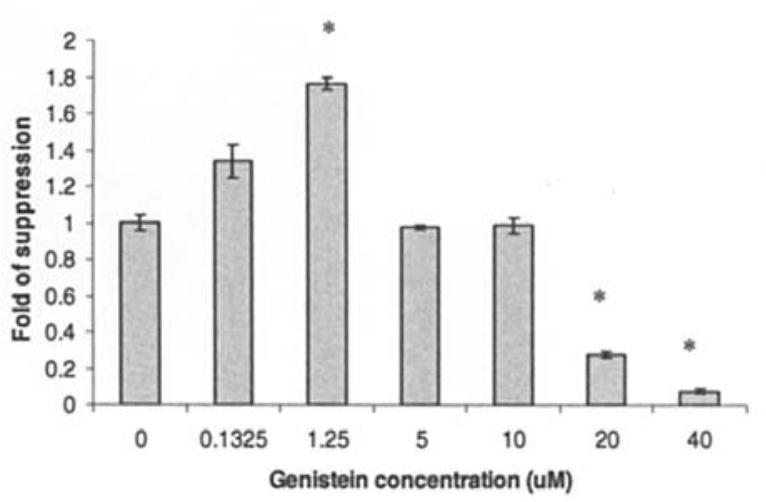

Figure 7. (A) Suppression of transgenic GFAP-lacZ by genistein. T6/GFAPlac $Z$ cells were treated with different concentrations of genistein and assayed for $\beta$-galactosidase activity at various time points (4, 8, 24, and $48 \mathrm{~h}$ ). Six columns (from left to right) represent six different concentrations of genistein $(0,0.1325,1.25,5,10,20$, and $40 \mu \mathrm{M})$. Data were presented as mean \pm SEM. $\mathrm{n}=6,{ }^{*} \mathrm{P}<0.05,{ }^{* *} \mathrm{P}<0.001$, when compared to treatment with 0 $\mu \mathrm{M}$ of genistein. (B) Time-dependent suppression of GFAP mRNA by genistein. T6/GFAP-lacZ cells were incubated with 10 or $20 \mu \mathrm{M}$ of genistein in low serum DMEM for various time points $(0,8,16,24,48$, and $72 \mathrm{~h}$ ). Endogenous level of rat GFAP mRNA was quantified with real-time RT-PCR. Data were presented as mean \pm SEM. $n=6,{ }^{*} \mathrm{P}<0.05,{ }^{* *} \mathrm{P}<0.001$, when compared to treatment at $0 \mathrm{~h}$. (C) Dose-dependent suppression of GFAP mRNA by genistein. T6/GFAP-lacZ cells were incubated in low serum DMEM containing various concentrations $(0,0.1325,1.25,5,10,20$, and $40 \mu \mathrm{M}$ ) of genistein for $48 \mathrm{~h}$, and endogenous rat GFAP mRNA was quantified with real-time RT-PCR. Data were presented as mean \pm SEM. $\mathrm{n}=6,{ }^{*} \mathrm{P}<0.001$, when compared to vehicle treatment.
$10 \mathrm{ng} / \mathrm{ml}$ of TGF- $\beta 1$ for $24 \mathrm{~h}$ showed a trend of attenuation ( $87 \%$ of the control, but not statistically significant) after a sequential incubation with $20 \mu \mathrm{M}$ of EGCG for an additional $2 \mathrm{~h}$. However a significant attenuation $(66 \%$ of the control, $\mathrm{P}<0.005)$ was observed for the TGF- 31 -treated cells concurrently incubated with $20 \mu \mathrm{M}$ of EGCG for $26 \mathrm{~h}$ (Fig. 5A). Similarly endogenous GFAP mRNA levels were significantly suppressed to $45 \%$ of the control $(\mathrm{P}<0.001)$ in the sequential treatment scheme ( $1 \mathrm{ng} / \mathrm{ml}$ of TGF- $\beta 1$ for $48 \mathrm{~h}$, followed by $5 \mu \mathrm{M}$ of EGCG for an additional $8 \mathrm{~h}$ ) and to $29 \%$ of the control $(\mathrm{P}<0.001)$ in the concurrent scheme $(1 \mathrm{ng} / \mathrm{ml}$ of TGF- 31 together with $5 \mu \mathrm{M}$ of EGCG for a total of $56 \mathrm{~h}$ ), as shown in Fig. 5B. In addition to TGF-B1 induction (2), we also showed here that another pro-fibrotic cytokine (i.e., $10 \mathrm{ng} / \mathrm{ml}$ of PDGF$\mathrm{BB})$ could induce the transgenic GFAP-lacZ expression by $24 \%(\mathrm{P}<0.01)$ (Fig. 6A) and the endogenous GFAP by $53 \%$ $(\mathrm{P}<0.05)$ (Fig. 6B) in the T6/GFAP-lacZ cells after being cultured for 48 and $24 \mathrm{~h}$ respectively in low serum DMEM. More importantly, the PDGF-induced GFAP elevation was greatly suppressed to $60 \%$ of the transgenic control $(\mathrm{P}<0.001$; Fig. 6A) and $8 \%$ of the endogenous control $(\mathrm{P}<0.001$; Fig. 6B) after incubation with $10 \mu \mathrm{M}$ of EGCG for two days.

Genistein suppressed GFAP expression. Previous studies have shown that genistein inhibited collagen synthesis and cell proliferation in HSCs $(5,7)$. To investigate whether genistein would exert any influence on the expression of GFAP, the T6/GFAP-lacZ cells were treated with various concentrations of genistein for 4, 8, 24 and $48 \mathrm{~h}$ and assayed for B-galactosidase activity and GFAP mRNA. As shown in Fig. 7A, genistein inhibited the GFAP-lacZ transgene expression in a dose- and time-dependent manner, however less potently than EGCG. Nevertheless, both compounds started to inhibit the transgene expression after only 2-4 h of incubation (Figs. 4A and 7A). The largest suppression (65\% of the control) was seen for $40 \mu \mathrm{M}$ of genistein at $24 \mathrm{~h}$ (Fig. 7A). By a time-course study of GFAP mRNA, a strong suppression (Fig. 7B) was observed for the cells treated with $20 \mu \mathrm{M}$ of genistein starting from $8 \mathrm{~h}(23 \%$ of the control; $\mathrm{P}<0.001)$ and lasting to at least $72 \mathrm{~h}(43 \%$ of the control; $\mathrm{P}<0.001)$. At a lower dose of genistein $(10 \mu \mathrm{M})$, effects were less predictable, ranging from suppression at $24 \mathrm{~h}$ to induction at $72 \mathrm{~h}$. A follow-up dose experiment confirmed that the reliable inhibitory concentration of genistein should be $>10 \mu \mathrm{M}$, e.g., at the 20-40 $\mu \mathrm{M}$ range (Fig. 7C).

Genistein attenuated GFAP elevation induced by TGF- $\beta 1$ or $P D G F-B B$. When $40 \mu \mathrm{M}$ of genistein and $10 \mathrm{ng} / \mathrm{ml}$ of TGF- $B 1$ were concurrently introduced into the T6/GFAP-lacZ cells for $48 \mathrm{~h}$, transgenic $\beta$-galactosidase activity was decreased to $43 \%$ of the TGF- $\beta 1$-alone control $(\mathrm{P}<0.005)$, whereas the suppressing effect was negligible in the sequential genistein treatment scheme (Fig. 8A). Reminiscently the TGF-ß31induced GFAP transcription was effectively blocked by $20 \mu \mathrm{M}$ of genistein in either the sequential $(26 \%$ of the control; $\mathrm{P}<0.001)$ or the concurrent $(14 \%$ of the control; $\mathrm{P}<0.001)$ treatment scheme (Fig. 8B). Finally, $40 \mu \mathrm{M}$ of genistein was also found to be quite effective in attenuating the PDGF-BBinduced elevation in the $\beta$-galactosidase activity, down- 
A

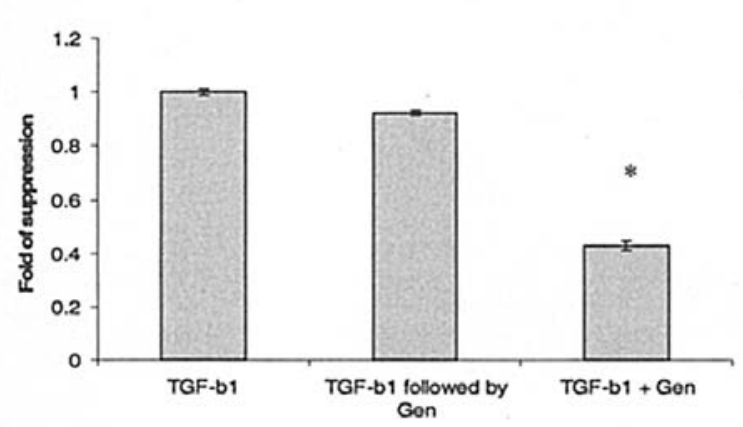

B

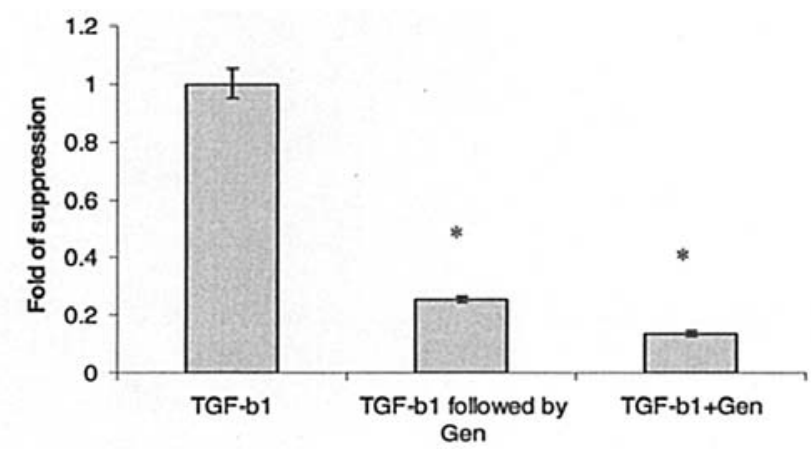

Figure 8. (A) Attenuation of TGF-ß1-induced T6/GFAP-lacZ activation by genistein. T6/GFAP-lacZ cells were subjected to different treatments: left column, $10 \mathrm{ng} / \mathrm{ml}$ TGF- 31 for $24 \mathrm{~h}$; middle column, $10 \mathrm{ng} / \mathrm{ml}$ TGF- $\beta 1$ for $24 \mathrm{~h}$ followed by $40 \mu \mathrm{M}$ of genistein for an additional $24 \mathrm{~h}$; and right column, $40 \mu \mathrm{M}$ genistein and $10 \mathrm{ng} / \mathrm{ml}$ TGF- $\beta 1$ for $48 \mathrm{~h}$; and $\beta$-galactosidase activity was assayed. Data are presented as mean $\pm \mathrm{SEM}$. $\mathrm{n}=6$, ${ }^{*} \mathrm{P}<0.005 \mathrm{when}$ compared to $10 \mathrm{ng} / \mathrm{ml}$ TGF-ß1 treated alone (left column). (B) Attenuation of TGF-ß1-induced GFAP mRNA by genistein. T6/GFAP-lacZ cells were subject to different treatments and the GFAP mRNA level was quantified with real-time RT-PCR. Left column, $1 \mathrm{ng} / \mathrm{ml}$ TGF- $31 \mathrm{for} 48 \mathrm{~h}$; middle column, $1 \mathrm{ng} / \mathrm{ml}$ TGF- 31 for $48 \mathrm{~h}$ followed by $20 \mu \mathrm{M}$ of genistein for an additional $8 \mathrm{~h}$; and right column, $20 \mu \mathrm{M}$ of genistein and $1 \mathrm{ng} / \mathrm{ml} \mathrm{TGF}-\beta 1 \mathrm{for} 56 \mathrm{~h}$. Data are presented as mean $\pm \mathrm{SEM}$. $\mathrm{n}=6,{ }^{*} \mathrm{P}<0.001$, when compared to $1 \mathrm{ng} / \mathrm{ml}$ TGF- $\beta 1$ treated alone sample (left column).

A

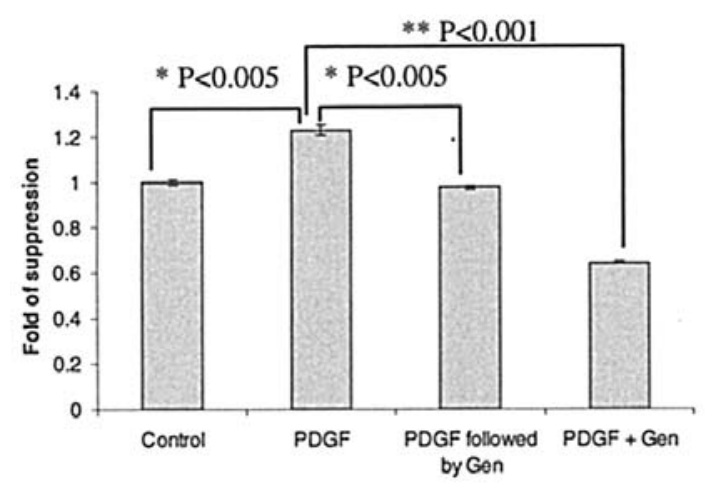

B

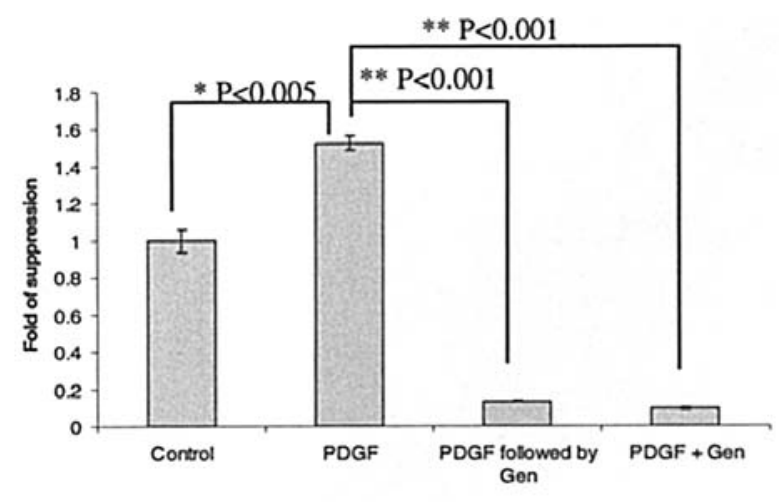

Figure 9. (A) Attenuation of PDGF-BB-induced T6/GFAP-lacZ activation by genistein. T6/GFAP-lacZ cells were subjected to different treatments, from left to right: column 1, vehicle control; column 2, $10 \mathrm{ng} / \mathrm{ml}$ PDGF-BB for $48 \mathrm{~h}$; column $3,10 \mathrm{ng} / \mathrm{ml}$ PDGF-BB for $48 \mathrm{~h}$ followed by $40 \mu \mathrm{M}$ of genistein for an additional $24 \mathrm{~h}$; and column $4,40 \mu \mathrm{M}$ of genistein and $10 \mathrm{ng} / \mathrm{ml} \mathrm{PDGF}-\mathrm{BB}$ for $72 \mathrm{~h}$. Data are presented as mean $\pm \mathrm{SEM}$. $\mathrm{n}=6$, ${ }^{*} \mathrm{P}<0.005,{ }^{* *} \mathrm{P}<0.001$. (B) Attenuation of PDGF-BB-induced GFAP mRNA elevation by genistein. T6/GFAP-lacZ cells were subjected to different treatments, and the endogenous GFAP mRNA level was quantified with real-time RT-PCR. From left to right: column 1, vehicle control; column 2, $10 \mathrm{ng} / \mathrm{ml}$ PDGF for 24 h; column 3 , $10 \mathrm{ng} / \mathrm{ml}$ PDGF for $24 \mathrm{~h}$ followed by $20 \mu \mathrm{M}$ of genistein for an additional $24 \mathrm{~h}$; and column $4,20 \mu \mathrm{M}$ of genistein and $10 \mathrm{ng} / \mathrm{ml} \mathrm{PDGF}$ for $48 \mathrm{~h}$. Data are presented as mean \pm SEM. $\mathrm{n}=6,{ }^{*} \mathrm{P}<0.005,{ }^{* *} \mathrm{P}<0.001$.

regulating to $79 \%(\mathrm{P}<0.005)$ and $48 \%(\mathrm{P}<0.001)$ of the PDGF-BB-alone control in the sequential and the concurrent schemes respectively (Fig. 9A). For endogenous GFAP, the transcription was inhibited even more dramatically by a lower concentration of genistein $(20 \mu \mathrm{M})$ to $8.6 \%(\mathrm{P}<0.001)$ and $6 \%(\mathrm{P}<0.001)$ of the PDGF-BB-alone control in the sequential and the concurrent schemes respectively (Fig. 9B).

EGCG attenuated GFAP and AP-1 proteins. To investigate whether the EGCG-mediated suppression in the endogenous GFAP mRNA was reflected at the protein level, total proteins were extracted from the T6/GFAP-lacZ cells treated with various concentrations of EGCG (from 0 to $20 \mu \mathrm{M}$ ) for $24 \mathrm{~h}$, and analyzed using Western blotting to estimate the GFAP level. As shown in Fig. 10A, the GFAP protein level was indeed decreased, in a dose-dependent manner, to $60 \%$ of the untreated control. Importantly the major marker for HSC activation and transdifferentiation, SMAA (smooth muscle $\alpha$-actin), was also significantly suppressed by $20 \mu \mathrm{M}$ of EGCG, $22 \%$ of the untreated control. It was interesting to note that the SMAA fiber assembly in an immortalized human HSC cell line TWNT-4 seemed to be influenced by the EGCG treatment (9). However no quantitative change in SMAA level was detected in non-immortalized parental human HSCs (i.e., the LI90) after treatment with $10 \mu \mathrm{M}$ of EGCG for up to $72 \mathrm{~h}(8)$.

Next to elucidate to what extent EGCG signaled through the AP-1 and NFKB pathways, nuclear protein extracts isolated from treated and untreated T6/GFAP-lacZ cells were analyzed for the expression of different members of AP-1 and NFkB complexes on Western blots. It was evident from Fig. 10B that many members of the Jun and Fos families were expressed in the untreated HSC-T6/lac Z cells at significant levels, including c-jun, Jun B, Jun D, c-fos, Fra-1 and Fra-2. 
A

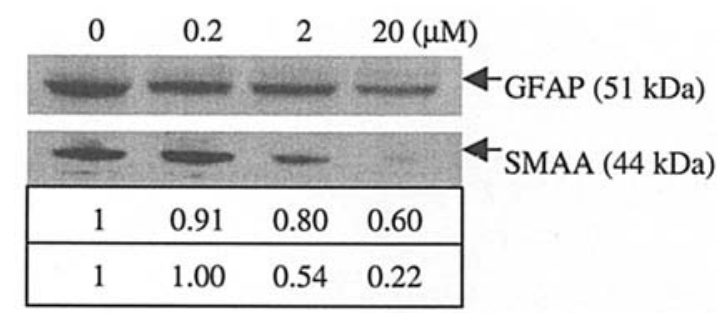

B

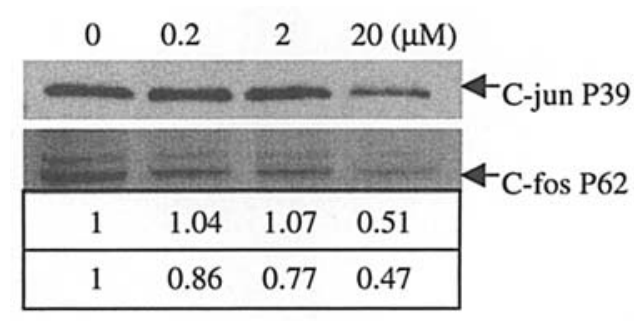

$0 \quad 20(\mu \mathrm{M})$

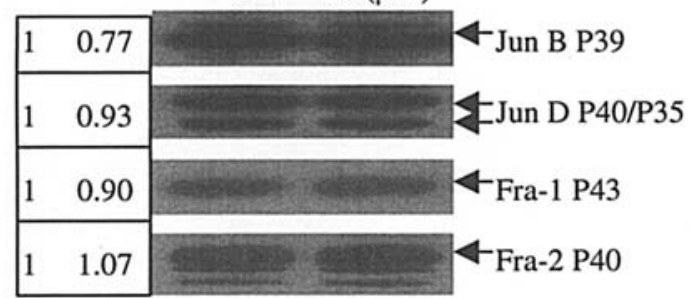

C

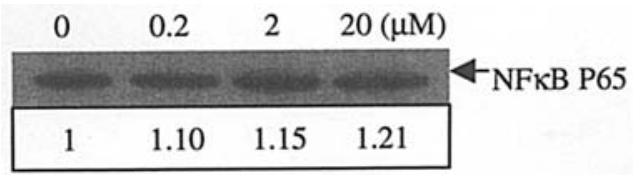

Figure 10. (A) Western blotting of GFAP and SMAA proteins in cells treated with EGCG. T6/GFAP-lacZ cells were treated with $0,0.2,2$ and $20 \mu \mathrm{M}$ of EGCG for $24 \mathrm{~h}$ in low serum DMEM. Total proteins $(15 \mu \mathrm{g})$ were resolved in a $4-12 \%$ gradient PAGE-SDS gel; target proteins were recognized by anti-GFAP (Dako) and anti-SMAA (Sigma) antibodies respectively, and visualized by ECL method (Amersham). For comparison of the same target protein, the densitometric value for the non-treated sample was normalized to 1. Quantitative comparison between different proteins is invalid. (B) Changes in AP-1 compositions in T6/GFAP-lacZ cells treated with EGCG. T6/GFAP-lacZ cells were treated with $0,0.2,2$, and $20 \mu \mathrm{M}$ of EGCG for $2 \mathrm{~h}$ in low serum DMEM. Nuclear protein $(15 \mu \mathrm{g})$ was resolved in $4-12 \%$ gradient PAGE-SDS gel, and probed with antibodies against different members of the Jun and Fos families (Santa Cruz Biotechnology), and visualized by ECL (Amersham). For comparison of the same target protein, densitometric value for the non-treated sample was normalized to 1 . Quantitative comparison between different proteins is invalid. (C) Western blotting of NFKB in cells treated with EGCG. T6/GFAP-lacZ cells were treated with $0,0.2,2$ and $20 \mu \mathrm{M}$ of EGCG for $2 \mathrm{~h}$ in low serum DMEM. Nuclear protein extracts $(15 \mu \mathrm{g})$ were resolved in a $4-12 \%$ gradient PAGESDS gel, and probed with an anti-NFkB P65 antibody (Abcam), and visualized by ECL (Amersham). For comparison of the same target protein, densitometric value for the non-treated sample was normalized to 1 .

In contrast, fos-B was expressed at a much lower level (not shown). More interestingly the two strongly interacting partners (c-jun and c-fos) were significantly down-regulated by $50 \%$ by a treatment with $20 \mu \mathrm{M}$ of EGCG for only $2 \mathrm{~h}$, while changes seen for the other members were less impressive. In contrast to $\mathrm{AP}-1, \mathrm{NF} \kappa \mathrm{B}$ was not suppressed,
A

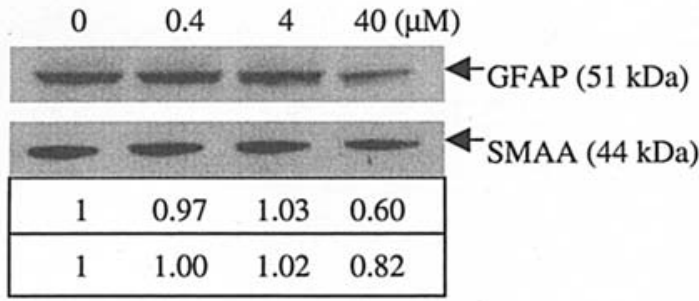

B
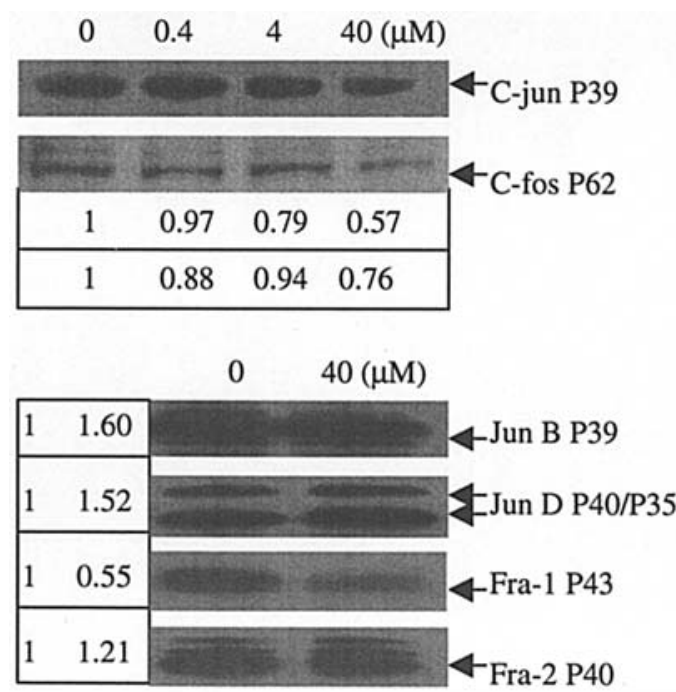

$\mathrm{C}$

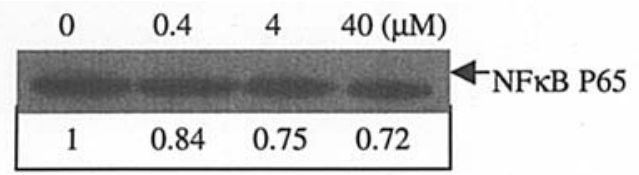

Figure 11. (A) Western blotting of GFAP and SMAA proteins in cells treated with genistein. T6/GFAP-lac Z cells were treated with $0,0.4,4$, and $40 \mu \mathrm{M}$ of genistein for $24 \mathrm{~h}$ in low serum DMEM. Total proteins $(15 \mu \mathrm{g})$ were resolved in a 4-12\% gradient PAGE-SDS gel; target proteins were recognized by anti-GFAP (Dako) and anti-SMAA (Sigma) antibodies respectively, and visualized by ECL (Amersham). For comparison of the same target protein, the densitometric value for the non-treated sample was normalized to 1 . Quantitative comparison between different proteins is invalid. (B) Changes in AP-1 compositions in T6/GFAP-lacZ cells treated with genistein. T6/GFAP-lacZ cells were treated with $0,0.4,4$, and $40 \mu \mathrm{M}$ of genistein for $24 \mathrm{~h}$ in low serum DMEM. Nuclear protein $(15 \mu \mathrm{g})$ was resolved in $4-12 \%$ gradient PAGE-SDS gel, and probed with antibodies against different members of the Jun and Fos families (Santa Cruz Biotechnology), and visualized by ECL (Amersham). For comparison of the same target protein, the densitometric value for the non-treated sample was normalized to 1 . Quantitative comparison between different proteins is invalid. (C) Western blotting of NFKB in cells treated with genistein. T6/GFAP-lacZ cells were treated with $0,0.4,4$ and $40 \mu \mathrm{M}$ of genistein for $24 \mathrm{~h}$ in low serum DMEM. Nuclear protein extracts $(15 \mu \mathrm{g})$ were resolved in a $4-12 \%$ gradient PAGESDS gel, and probed with an anti-NFKB P65 antibody (Abcam), and visualized by ECL (Amersham). For comparison of the same target protein, the densitometric value for the non-treated sample was normalized to 1 .

but instead increased slightly under the EGCG treatment regime (Fig. 10C), for which there was no ready explanation.

Genistein similarly attenuated GFAP, AP-1 and NFKB at the protein level. For treatment with genistein, the inhibitory effect on GFAP protein was comparable to that by EGCG 
A
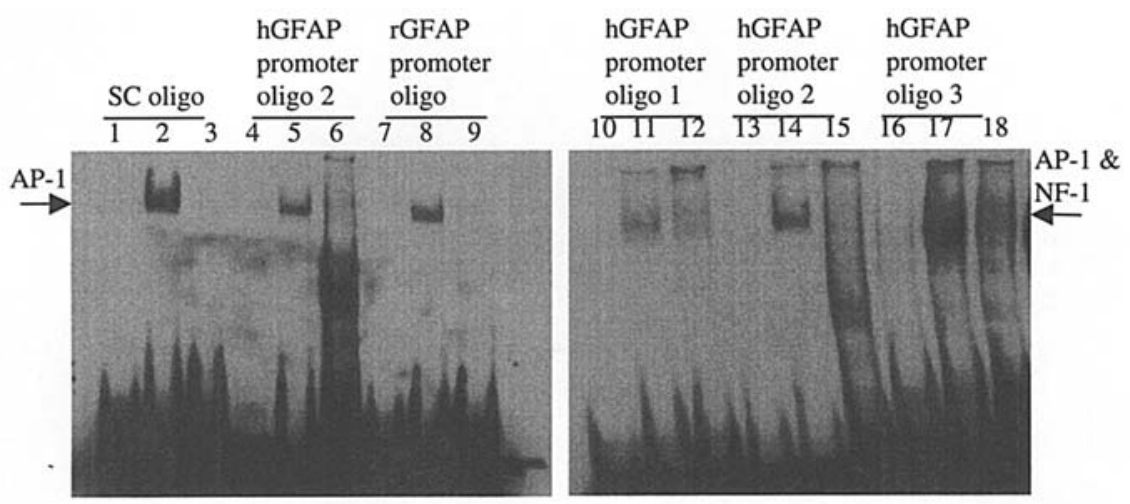

B

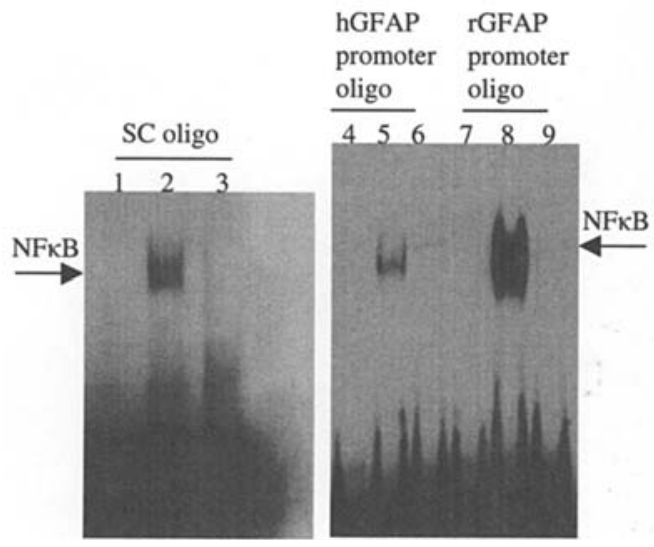

Figure 12. (A) Electrophoresis mobility shift assay (EMSA) of AP-1. Nuclear extracts (10 $\mu \mathrm{g})$ from T6/GFAP-lacZ cells were used to bind with oligos, human GFAP promoter and rat GFAP promoter (Santa Cruz Biotechnology) as a positive control. Lanes 1, 4, 7, 10, 13, and 16 were biotinylated with oligos alone; lanes $2,5,8,11,14$, and 17 were nuclear extracts plus labeled oligos; lanes $3,6,9,12,15$, and 18 were mixtures of nuclear extracts, labeled oligos and 200 folds of excessive unlabeled oligos. (B) Electrophoresis mobility shift assay (EMSA) of NFkB. Nuclear protein extracts (10 $\mu$ g) from T6/GFAP-lacZ cells were used to bind with oligos, human GFAP promoter and rat GFAP promoter (Santa Cruz Biotechnology). Lanes 1, 4, and 7 were biotinylated oligos alone; lanes 2, 5, and 8 were nuclear extracts plus labeled oligos; lanes 3, 6, and 9 were mixtures of nuclear extracts, labeled oligos and 200 folds of excessive unlabeled oligos.

(62\% of the untreated control), while the effect on SMAA was less pronounced (Fig. 11A). Similarly genistein exerted significant inhibition on AP-1 signaling, with primary effects seen on the c-jun and c-fos members, while its effects on other transcription factors were more complex, ranging from induction to inhibition by roughly $50 \%$ in either direction (Fig. 11B). In contrast to EGCG, genistein (40 $\mu \mathrm{M}$ for $24 \mathrm{~h}$ ) decreased the NFкB level by $\sim 30 \%$ (Fig. 11C).

Transcription factors bound to $A P-1$ and $N F \kappa B$ sites on the GFAP promoter. To find out whether the transcription factors expressed in the T6/GFAP-lacZ cells were functional, DNA oligonucleotides (Table I) designed from rat GFAP promoter $(11,12)$ and from the 2.2-kb human GFAP (13) were synthesized for performing EMSA (electrophoresis mobility shift assay) experiments using nuclear extracts from the T6/GFAP-lacZ cells. As illustrated in Fig. 12A, for AP-1 binding both the rGFAP promoter oligo and hGFAP promoter oligo 2, which differed from each other by a single base pair in the non-consensus region, displayed a similar binding intensity and pattern. In addition, hGFAP promoter oligo 1 (with only three base pairs 3 ' to the binding consensus) showed a significant decrease in binding, whereas hGFAP promoter oligo 3 (containing AP-1 and NF-1 sites from -1593 to -1565) showed a significant increase in gel shift signal, suggesting a cooperative binding between AP-1 and NF-1, and reminiscent of an earlier observation for NF-1-like factor and CRF (cAMP-responsive element binding factor) in rat liver nuclear extracts (14). It has been shown that NF-1, especially in cooperation with AP-1, is critical to GFAP expression in astrocytes $(12,15,16)$.

In contrast to the AP- 1 site, the $\mathrm{NF \kappa B}$ binding consensus in the rat GFAP promoter was different from that in the 2.2-kb hGFAP promoter and the positive control (SC oligo, Table I). This difference could contribute largely to the favorable binding to rat oligo by endogenous rat $\mathrm{NF \kappa B}$ transcription factors (Fig. 12B).

\section{Discussion}

EGCG significantly suppressed GFAP via AP-1 signaling. We showed here for the first time that EGCG suppressed both GFAP-lacZ (Fig. 4A) and endogenous GFAP (Fig. 4B and $\mathrm{C}$ ) in HSC in a time- and dose-dependent manner. It was noted that the suppression occurred within the initial 2-8 $\mathrm{h}$ (Fig. 4A and B). This acute response could be partially due to rapid blocking of PDGF- $3 \mathrm{R}$ phosphorylation via AP-1 signaling (6), whereas longer suppression (up to 48 h, Fig. 4A and $\mathrm{B}$ ) could be attributed to a more direct interference of EGCG with AP-1 complex assembly (6) and with the binding 
of PDGF-BB to PDGF-ßR on the surfaces of HSCs (8). At the protein level, both GFAP and SMAA were significantly decreased after incubation with EGCG of various concentrations (Fig. 10A). Another observation was that EGCG at a concentration as low as $133 \mathrm{nM}$ was capable of inhibiting endogenous GFAP mRNA by as much as $66 \%$ in $48 \mathrm{~h}$ (Fig. 4C). It was interesting to note that the concentration of $133 \mathrm{nM}$ is lower than the maximum concentration ( $326 \mathrm{nM}$ ) of EGCG in human plasma after drinking $3 \mathrm{~g}$ of green tea (10), therefore physiologically relevant.

We previously showed that TGF- $\beta 1$ induced GFAP expression in HSCs (2). Here we provided evidence that another pro-fibrotic cytokine PDGF-BB could also induce GFAP expression in the same HSC cell line on a similar scale (Fig. 6A and B). Crucially the elevation in the endogenous or in the transgenic GFAP as induced by TGF- 31 (Fig. 5A and B) or PDGF-BB (Fig. 6A and B) was effectively suppressed by EGCG in a time- and dose-dependent manner. We speculated here that many of the pro-fibrogenic cytokines and EGCG share the same multiple signaling pathways (17). Consequently the net effects of EGCG suppression (especially in the concurrent treatment scheme with EGCG and cytokine) through different pathways could be directly and indirectly converged at the AP-1 signaling juncture. An AP-1 binding site was identified in the $\mathrm{B}$ box region $(-1612$ to $-1489 \mathrm{bp})$ of the 2.2-kb hGFAP promoter (13). A binding site was also reported in the 1.9-kb rat GFAP promoter (12). It was shown in the current study that the expression of two strong heterodimers (c-jun and c-fos), but not other members of the AP-1 complex, were significantly suppressed by acute $(2 \mathrm{~h})$ treatment with EGCG (Fig. 10B). It was reported that the AP-1 level was either very low or absent (19) in freshly isolated quiescent HSCs, but greatly elevated in activated HSCs (18-20). In this sense, EGCG treatment 'reverted' activated HSC-T6 cells back to a less activated state. By this scenario, the degree of HSC activation prior to transdifferentiated to myofibroblasts (MFBs) in vitro could be hypothetically ranked according to GFAP (or GFAP-lacZ) expression level in the following order: (fresh HSCs) $<$ (cultured HSCs + EGCG) $<$ (cultured HSCs) $<$ (cultured HSCs + profibrotic cytokine + EGCG) $<$ (cultured HSCs + pro-fibrotic cytokine). Finally NFkB expression was not suppressed by EGCG treatment for $2 \mathrm{~h}$ (Fig. 10C), suggesting NFKB could be a slower component in mediating EGCG suppression.

Genistein suppressed GFAP via AP-1 signaling. Genistein signals through the RTK pathway and by inhibiting tyrosine kinase, CDK, and P53 etc., inhibits cell proliferation and enhances apoptosis. Compared to EGCG, less is known about genistein for its effects on HSCs. Nevertheless there is evidence that genistein inhibited HSC proliferation, and expression of SMAA and $\alpha 1$ (I) collagen in HSCs, presumably through suppression of AP-1 activity $(5,7)$. In addition, the AP-1-suppressing effect by genistein is also documented in human breast cancer cell lines (21), indicating that genistein signaling through AP-1 is not a restricted phenomenon in HSCs. We showed here that treatment with genistein $(40 \mu \mathrm{M}$ for $24 \mathrm{~h}$ ) attenuated the expression level of GFAP and SMAA (Fig. 11A) and AP-1 transcription factors (Fig. 11B). Similarly genistein attenuated GFAP expression, though less robustly, through multiple pathways used by EGCG (such as RTK, ERK and Akt), and its signaling consequence could also be largely integrated at the AP-1 juncture, with minor signaling at the NFKB juncture (Fig. 11C). It was noted that an $\mathrm{NF}$ B binding site existed at the immediate region (approximately -60 to $-80 \mathrm{bp}$ ) in both the 2.2-kb hGFAP (13) and the rGFAP (12) promoters.

GFAP promoter shares many binding sites with other profibrogenic gene promoters. The 2.2-kb hGFAP promoter is enriched with multiple binding sites for transcriptional factors and cytokines, such as AP-1, AP-2, Sp-1, NF-1, NFkB, TßRE, and CRE (13), which may be necessary for conferring specificity and responsiveness seen in astrocytes $(13,22,23)$, and more recently in HSC (2). Particularly the AP-1 binding site was also found in the promoter regions of other HSC biomarkers, such as vimentin (24) and SMAA (25). Furthermore many of these binding sites were present in major genes directly implicated in hepatic fibrosis. For example, binding sites for AP-1, AP-2, Sp-1, NF-1 and CRE have been documented for collagen (COL1A1 and COL1A2) promoters (26-30). Both pro-fibrotic activators (e.g., PDGF-BB and leptin) and anti-fibrotic inhibitors (e.g., N-acetyl-Lcysteine) were shown to signal through these sites in HSCs $(20,29)$. Additional pro-fibrogenic genes with AP-1 binding site in their promoters for activation include laminin (31-33), fibronectin (34), and TIMP-1 (19).

GFAP as a biomarker for screening anti-fibrotic and antiinflammatory agents. Based on the literatures and our current observations, it seems that GFAP's position in HSC activation/ inhibition is parallel with other fibrogenic endpoint molecules, such as collagen, fibronectin, laminin and SMAA. More critically the GFAP promoter not only contains a comprehensive set of binding sites relevant to HSC activation and inhibition, but also at the same time preserves cellularexpression specificity for HSC (2) and responsiveness to both fibrogenic activators and inhibitors (current study). Rooted in these observations, we would propose GFAP (and its transgenic surrogate) as a broad-based biomarker for studying HSC activation and inhibition. It is envisioned that a HSCbased, high-throughput system can be constructed using the GFAP promoter in conjunction with a real-time reporter for first-tier screening of anti-fibrotic compounds and protein inhibitors.

It is important to bear in mind that the $\mathrm{NF \kappa B}$ binding site ( -80 to $-60 \mathrm{bp}$ ) in the $2.2-\mathrm{kb}$ hGFAP promoter did not fully capture NFkB signaling in the heterogeneous transenvironment, especially when compared to the full-length rat endogenous GAFP gene (Fig. 12B). Implications of this observation are that for profiling anti-inflammatory inhibitors (presumably signaling through the $\mathrm{NF \kappa B}$ ), it is best to use the 2.2-kb hGFAP promoter in a human cell line, or conversely to mutate the human NFKB site using the rat consensus for fully realizing the screening potential.

Finally, the precise role of GFAP, as well as other members of intermediate filaments (desmin, vimentin and nestin), in the pathobiology of hepatic fibrosis remains to be demonstrated, though it was shown that different members of the intermediate filament family are required to assemble 
into normal intermediate filament bundles in HSCs (35). If members of this family could be causatively implicated in hepatic fibrogenesis, they would represent additional direct targets for the development of future anti-fibrotic therapies.

\section{Acknowledgments}

The research was supported by the Biomedical Research Council (BMRC), and the Institute of Bioengineering and Nanotechnology (IBN), Singapore.

\section{References}

1. Friedman SL: Liver fibrosis-from bench to bedside. J Hepatol 38 (suppl 1): 38-53, 2003.

2. Maubach G, Lim MCC, Zhang CY and Zhuo L: GFAP promoter directs $l a c Z$ expression specifically in a rat hepatic stellate cell line. World J Gastroenterol 12: 723-730, 2006.

3. Vogel S, Piantedosi R, Frank J, Lalazar A, Rockey DC, Friedman SL and Blaner WS: An immortalized rat liver stellate cell line (HSC-T6): a new cell model for the study of retinoid metabolism in vitro. J Lipid Res 41: 882-893, 2000.

4. Chen A, Zhang L, Xu J and Tang J: The antioxidant (-)epigallocatechin-3-gallate inhibits activated hepatic stellate cell growth and suppresses acetaldehyde-induced gene expression. Biochem J 368: 695-704, 2002.

5. Liu X J, Yang L, Mao YQ, Wang Q, Huang MH, Wang YP and Wu HB: Effects of the tyrosine protein kinase inhibitor genistein on the proliferation, activation of cultured rat hepatic stellate cells. World J Gastroenterol 8: 739-745, 2002.

6. Chen A and Zhang L: The antioxidant (-)-epigallocatechin-3gallate inhibits rat hepatic stellate cell proliferation in vitro by blocking the tyrosine phosphorylation and reducing the gene expression of platelet-derived growth factor-beta receptor. J Biol Chem 278: 23381-23389, 2003.

7. Kang LP, Qi LH, Zhang JP, Shi N, Zhang M, Wu TM and Chen J: Effect of genistein and quercetin on proliferation, collagen synthesis, and type I procollagen mRNA levels of rat hepatic stellate cells. Acta Pharmacol Sin 22: 793-796, 2001.

8. Sakata R, Ueno T, Nakamura T, Sakamoto M, Torimura T and Sata M: Green tea polyphenol epigallocatechin-3-gallate inhibits platelet-derived growth factor-induced proliferation of human hepatic stellate cell line LI90. J Hepatol 40: 52-59, 2004.

9. Higashi N, Kohjima M, Fukushima M, Ohta S, Kotoh K, Enjoji M, Kobayashi $\mathrm{N}$ and Nakamuta M: Epigallocatechin-3-gallate, a green-tea polyphenol, suppresses Rho signaling in TWNT-4 human hepatic stellate cells. J Lab Clin Med 145: 316-322, 2005.

10. Yang CS, Chen L, Lee MJ, Balentine D, Kuo MC and Schantz SP: Blood and urine levels of tea catechins after ingestion of different amounts of green tea by human volunteers. Cancer Epidemiol Biomarkers Prev 7: 351-354, 1998.

11. Condorelli DF, Nicoletti VG, Barresi V, Caruso A, Conticello S, de Vellis $\mathbf{J}$ and Giuffrida Stella AM: Tissue-specific DNA methylation patterns of the rat glial fibrillary acidic protein gene. J Neurosci Res 39: 694-707, 1994.

12. Krohn K, Rozovsky I, Wals P, Teter B, Anderson CP and Finch CE: Glial fibrillary acidic protein transcription responses to transforming growth factor-b1 and interleukin- $1 \mathrm{~b}$ are mediated by a nuclear factor-1-like site in the near-upstream promoter. J Neurochem 72: 1353-1361, 1999.

13. Besnard F, Brenner M, Nakatani Y, Chao R, Purohit HJ and Freese E: Multiple interacting sites regulate astrocyte-specific transcription of the human gene for glial fibrillary acidic protein. J Biol Chem 266: 18877-18883, 1991.

14. Lu GH, Schlichter D and Wicks WD: Interaction of a nuclear factor 1-like protein with a cAMP response element-binding protein in rat liver. Int J Biochem 24: 455-464, 1992.

15. Gopalan SM, Wilczynska KM, Konik BS, Bryan L and Kordula T: Astrocyte-specific expression of the alpha 1-antichymotrypsin and glial fibrillary acidic protein genes requires activator protein-1. J Biol Chem 281: 1956-1963, 2006.

16. Gopalan SM, Wilczynska KM, Konik BS, Bryan L and Kordula T: Nuclear factor-1-x regulates astrocyte-specific expression of the alpha 1-antichymotrypsin and glial ibrillary acidic protein genes. J Biol Chem 281: 13126-13133, 2006.
17. Shimizu M and Weinstein IB: Modulation of signal transduction by tea catechins and related phytochemicals. Mutat Res 591: 147-160, 2005.

18. Poulos JE, Weber JD, Bellezzo JM, Di Bisceglie AM, Britton RS, Bacon BR and Baldassare JJ: Fibronectin and cytokines increase JNK, ERK, AP-1 activity, and transin gene expression in rat hepatic stellate cells. Am J Physiol 273: 804-811, 1997.

19. Bahr MJ, Vincent KJ, Arthur MJ, Fowler AV, Smart DE, Wright MC, Clark IM, Benyon RC, Iredale JP and Mann DA: Control of the tissue inhibitor of metalloproteinases-1 promoter in culture-activated rat hepatic stellate cells: regulation by activator protein-1 DNA binding proteins. Hepatology 29: 839-848, 1999.

20. Segawa M, Kayano K, Sakaguchi E, Okamoto M, Sakaida I and Okita K: Antioxidant, N-acetyl-L-cysteine inhibits the expression of the collagen a2 (I) promoter in the activated human hepatic stellate cell line in the absence as well as the presence of transforming growth factor-b. Hepatol Res 24: 305-315, 2002.

21. Dampier K, Hudson EA, Howells LM, Manson MM, Walker RA and Gescher A: Differences between human breast cell lines in susceptibility towards growth inhibition by genistein. Br J Cancer 85: 618-624, 2001.

22. Brenner M, Kisseberth WC, Su Y, Besnard F and Messing A: GFAP promoter directs astrocyte-specific expression in transgenic mice. J Neurosci 14: 1030-1037, 1994.

23. Zhuo L, Sun B, Zhang CL, Fine A, Chiu SY and Messing A: Live astrocytes visualized by green fluorescent protein in transgenic mice. Dev Biol 187: 36-42, 1997.

24. Pieper FR, Van de Klundert FA, Raats JM, Henderik JB, Schaart G, Ramaekers FC and Bloemendal H: Regulation of vimentin expression in cultured epithelial cells. Eur J Biochem 210: 509-519, 1992

25. Gonzalez Bosc LV, Layne JJ, Nelson MT and Hill-Eubanks DC: Nuclear factor of activated $\mathrm{T}$ cells and serum response factor cooperatively regulate the activity of an alpha-actin intronic enhancer. J Biol Chem 280: 26113-26120, 2005.

26. Houglum K, Buck M, Alcorn J, Contreras S, Bornstein P and Chojkier M: Two different cis-acting regulatory regions direct cell-specific transcription of the collagen alpha 1(I) gene in hepatic stellate cells and in skin and tendon fibroblasts. J Clin Invest 96: 2269-2276, 1995.

27. Miao K, Potter JJ, Anania FA, Rennie-Tankersley L and Mezey E: Effect of acetaldehyde on Sp1 binding and activation of the mouse alpha 2(I) collagen promoter. Arch Biochem Biophys 341: 140-152, 1997.

28. Vergeer WP, Sogo JM, Pretorius PJ and de Vries WN: Interaction of Ap1, Ap2, and Sp1 with the regulatory regions of the human pro-alpha1(I) collagen gene. Arch Biochem Biophys 377: 69-79, 2000.

29. Saxena NK, Saliba G, Floyd JJ and Anania FA: Leptin induces increased alpha2(I) collagen gene expression in cultured rat hepatic stellate cells. J Cell Biochem 89: 311-320, 2003.

30. Rippe RA and Brenner DA: From quiescence to activation: Gene regulation in hepatic stellate cells. Gastroenterology 127: 1260-1262, 2004.

31. Matsui T: Differential activation of the murine laminin B1 gene promoter by RAR alpha, ROR alpha, and AP-1. Biochem Biophys Res Commun 220: 405-410, 1996.

32. Virolle T, Monthouel MN, Djabari Z, Ortonne JP, Meneguzzi G and Aberdam D: Three activator protein-1-binding sites bound by the Fra- 2.JunD complex cooperate for the regulation of murine laminin alpha3 A (lama3 A) promoter activity by transforming growth factor-beta. J Biol Chem 273: 17318-17325, 1998.

33. Olsen J, Kirkeby LT, Brorsson MM, Dabelsteen S, Troelsen JT, Bordoy R, Fenger K, Larsson LI and Simon-Assmann P: Converging signals synergistically activate the LAMC2 promoter and lead to accumulation of the laminin gamma 2 chain in human colon carcinoma cells. Biochem J 371: 211-221, 2003.

34. Tamura K, Chen YE, Lopez-Ilasaca M, Daviet L, Tamura N, Ishigami T, Akishita M, Takasaki I, Tokita Y, Pratt RE, Horiuchi M, Dzau VJ and Umemura S: Molecular mechanism of fibronectin gene activation by cyclic stretch in vascular smooth muscle cells. J Biol Chem 275: 34619-34627, 2000.

35. Geerts A, Eliasson C, Niki T, Wielant A, Vaeyens F and Pekny M: Formation of normal desmin intermediate filaments in mouse hepatic stellate cells requires vimentin. Hepatology 33: 177-188, 2001. 